JPPKMI 2 (2) (2021)
JURNAL PENELITIAN DAN PENGEMBANGAN
KESEHATAN MASYARAKAT INDONESIA
JPPKMI

\title{
Pengaruh Suplementasi Minuman Mikronutrien Terhadap Status Besi dan Status Vitamin A Anak Usia Dini Malnutrisi Jangka Panjang di Wilayah Miskin Perkotaan
}

\author{
Siti Zulaekah ${ }^{1}$, Listyani Hidayati ${ }^{1}$, Setiyo Purwanto ${ }^{2}$, Yuli Kusumawati ${ }^{3} \bowtie$ \\ ${ }^{1}$ Prodi Gizi Fakultas Ilmu Kesehatan Universitas Muhammadyah Surakarta \\ ${ }^{2}$ Fakultas Psikologi Universitas Muhammadyah Surakarta \\ ${ }^{3}$ Prodi Kesehatan Masyarakat Fakultas Ilmu Kesehatan Universitas Muhammadiyah Surakarta
}

\section{Info Artikel Abstrak}

Sejarah Artikel:

Diterima Juni 2021

Disetujui November 2021

Dipublikasi Desember 2021

Keywords:

Early Childhood,

Malnutrition,

Supplementation, Iron

Status; Vitamin A Status

URL:

https://iournal.unnes.ac.j d/sju/index.php/ippkmi /article/view/52117

\begin{abstract}
Malnutrisi merupakan penyebab utama hampir separuh anak-anak meninggal di negara sedang berkembang. Bila tidak ditangani dengan serius, diduga akan terjadi peningkatan anak-anak malnutrisi, yang sangat berkaitan dengan defisiensi berbagai mikronutrien, baik vitamin maupun mineral. Penelitian ini bertujuan untuk mengetahui pengaruh jangka panjang malnutrisi terhadap status besi dan status vitamin A anak usia dini setelah mendapat minuman suplemen. Jenis penelitian ini adalah quasi eksperimen. Subjek penelitian ini adalah anak usia 1-3 tahun yang mengalami malnutrisi. Status hemoglobin anak dianalisis dengan metode cyanmethemoglobin, untuk status Fe dilakukan dengan pengukuran serum ferritin metode ELISA dan mengukur status vitamin A dilakukan dengan metode penentuan serum retinol dengan cara HPLC.Intervensi minuman suplemen diberikan untuk satu kali pemberian pada pagi hari diberikan selama 6 hari dalam 1 minggu selama 12 minggu intervensi. Hasil penelitian menunjukkan bahwa intervensi minuman suplemen dapat menurunkan angka kejadian anemia pada anak yang malnutrisi sebesar $13,2 \%$. Pemberian minuman suplemen dapat meningkatkan status feritin sebesar $23,7 \%$. Hal ini menunjukkan bahwa minuman suplemen efektif meningkatkan status feritin anak yang malnutrisi. Meskipun sudah diberikan intervensi minuman suplemen pada anak yang malnutrisi akan tetapi terdapat peningkatan jumlah subjek yang mempunyai kadar retinol yang tidak normal sebesar 9,2 \%.
\end{abstract}

\section{Abstract}

Malnutrition is the leading cause of nearly half of child deaths in developing countries. If this problem is not taken seriously, it is suspected that there will be an increase in malnourished children, which is closely related to the deficiency of various micronutrients, both vitamins and minerals. This study aims to determine the long-term effect of malnutrition on iron status and vitamin A status of early childhood after receiving supplements. This type of research is a quasi-experimental. The subjects of this study were children aged 1-3 years who were malnourished. Children's hemoglobin status was analyzed by cyanmethemoglobin method, Fe status was measured by serum ferritin ELISA method and vitamin A status was measured by HPLC method for determination of serum retinol. weeks during the 12-week intervention. The results showed that the supplement drink intervention could reduce the incidence of anemia in malnourished children by $13.2 \%$. The supplement drink treatment can increase ferritin status by $23.7 \%$. Supplementary drinks are effective to improve ferritin status in malnourished children. Although the supplement drink intervention was given to malnourished children, there was an increase in the number of subjects who had abnormal retinol levels by $9.2 \%$.

Alamat korespondensi:

Gatak, Pabelan, Kec. Kartasura,

Kabupaten Sukoharjo, Jawa Tengah 57169

E-mail: vuli.kusumawati@ums.ac.id 


\section{PENDAHULUAN}

Malnutrisi merupakan masalah utama yang menimpa anak-anak di dunia, dan membahayakan bagi anak-anak tersebut maupun negara. Malnutrisi dapat membebani sebuah negara miskin hingga $3 \%$ dari pendapatan kotor negara. Bila tidak ditangani dengan serius, maka diduga akan terjadi peningkatan anak-anak malnutrisi. Berdasarkan laporan Databoks, Hasil Riset Kesehatan Dasar (Riskesdas) Kementerian Kesehatan 2018 menunjukkan $17,7 \%$ bayi usia di bawah 5 tahun (balita) masih mengalami masalah gizi. Angka tersebut terdiri atas balita yang mengalami gizi buruk sebesar 3,9\% dan yang menderita gizi kurang sebesar 13,8\%(Databoks, 2018). Ada tren penurunan jumlah bayi yang menderita gizi buruk dan kurang gizi pada Riskesdas 2013 (Kemenkes, 2013). Dalam Rencana Pembangunan Jangka Menengah Nasional (RPJMN) 2019, bayi yang mengalami masalah gizi ditargetkan turun menjadi $17 \%$. Adapun prevalensi balita yang mengalami stunting (tinggi badan di bawah standar menurut usia) sebesar $30,8 \%$, turun dibanding hasil Riskesdas 2013 sebesar 37,2\%. Fakta menunjukkan bahwa angka kematian akibat penyakit infeksi pada anak yang malnutrisi 3 hingga 27 kali lebih besar daripada anak-anak yang gizinya baik, sehingga malnutrisi merupakan faktor risiko yang signifikan penyebab kematian pada anak (UNS/SCN, 2005).

Beberapa hasil penelitian menunjukkan malnutrisi sangat berkaitan dengan defisiensi berbagai mikronutrien, baik vitamin maupun mineral. Defisiensi mikronutrien, termasuk vitamin A, zat besi dan seng menimpa lebih dari 3 milyar orang di dunia. Berdasarkan penelitian yang dilakukan oleh Centers for Disease Control and Prevention (CDC), anak usia 1-3 tahun memiliki resiko tinggi untuk defisiensi besi (Brotanek, 2008). Penelitian sebelumnya menunjukkan bahwa prevalensi anemia pada anak malnutrisi sebesar $25 \%$. Anak malnutrisi yang anemia mempunyai berat badan, tinggi badan, dan Z-Score BB/U yang lebih rendah dibandingkan dengan anak malnutrisi yang tidak anemia. Skor perkembangan motorik kasar, motorik halus, dan perkembangan bahasa anak malnutrisi yang anemia lebih rendah dibandingkan dengan anak yang tidak anemia (Zulaekah, 2014)

Anak-anak malnutrisi tidak mempunyai cadangan lemak dan sangat sedikit otot. Perkembangan otak menjadi lambat, karena anak-anak mengalami sakit karena tubuh tidak mampu melawan infeksi. Malnutrisi memberikan kontribusi pada tingginya rata-rata angka kematian di negara sedang berkembang. Tubuh membutuhkan mikronutrien dari makanan karena tubuh tidak dapat membuat seluruh mikronutrien ini untuk kenormalan fungsi tubuh. Mikronutrien ini termasuk vitamin $A$, vitamin $B$, vitamin $C$, folat, seng, kalsium, iodium dan besi. Defisiensi vitamin A merupakan masalah kesehatan yang sangat serius di dunia, karena defisiensi ini penyebab utama terjadinya kebutaan pada anak-anak. Makanan yang difortifikasi dan meningkatkan konsumsi buah dan sayur dalam makanan juga penting sebagai salah satu cara untuk mengurangi terjadinya defisiensi vitamin A (Torpy, 2004).

Malnutrisi akibat defisiensi mikronutrien biasanya terjadi secara simultan. Hasil penelitian Hyder (2007) di wilayah pedesaan Bangladesh menunjukkan bahwa intervensi multimikronutrien dapat menurunkan kejadian anemia lebih besar dibandingkan dengan kelompok kontrol, demikian pula dengan perubahan status vitamin A dan status $\mathrm{Zn}$ yang menunjukkan efek yang lebih baik dibanding dengan kelompok kontrol. Hasil penelitian lain yang dilakukan pada remaja wanita menunjukkan bahwa suplementasi vitamin A, besi dan seng lebih efektif meningkatkan hemoglobin dibanding yang mendapatkan suplementasi vitamin A dan besi (Cusick, 2005). Defisiensi seng biasanya juga diikuti oleh defisiensi vitamin A. Defisiensi seng atau malnutrisi protein akan mengganggu fungsi vitamin A dengan jalan mencegah tingkat pembebasan normal dari penyimpanannya dalam hati, sehingga apabila seseorang anemia karena kekurangan vitamin A perlu diberikan 
suplemen kombinasi vitamin A dan seng untuk lebih mengefektifkan peningkatan kadar hemoglobin. Pada penelitian lain yang bertujuan untuk mengetahui hubungan vitamin A dengan peningkatan hemoglobin menunjukkan bahwa pemberian vitamin dan besi lebih meningkatkan kadar hemoglobin dibandingkan yang hanya mendapatkan vitamin A saja. Penelitian ini dilakukan pada anak sekolah di Tanzania yang diberi suplemen setiap hari selama tiga bulan.

Berger (2007) menyatakan bahwa distribusi kapsul vitamin A dosis tinggi secara periodik adalah sebuah intervensi yang efektif untuk meningkatkan kelangsungan hidup anakanak di negara sedang berkembang. Berdasarkan data sistem surveilen gizi, terdapat perbedaan status gizi, proporsi anak yang anemia, morbiditas (diare dan demam) yang signifikan antara anak yang mendapatkan kapsul dan anak yang tidak mendapatkan kapsul. Walaupun kehilangan akses terhadap intervensi program kesehatan yang lain seperti imunisasi dan faktor-faktor demografi juga memberikan kontribusi terhadap terjadinya malnutrisi pada anak-anak, namun terbukti bahwa suplementasi vitamin A dapat memaksimalkan kelangsungan hidup anak.

$$
\text { Adu-Afarwuah }
$$

mengungkapkan bahwa fortifikasi berbagai vitamin dan mineral dalam bentuk makanan pelengkap bayi terbukti dapat menurunkan prevalensi defisiensi besi pada bayi dan terbukti dapat meningkatkan perkembangan motorik anak dibandingkan dengan yang tidak mendapat intervensi ini atau yang hanya mendapat makanan yang difortifikasi minerel tunggal. Öhlund (2008) membuktikan pada anak-anak yang bergizi baik (tidak malnutrisi), prevalensi anak-anak yang mengalami defisiensi besi lebih rendah dibandingkan dengan anakanak yang bergizi baik. Kaitan antara status vitamin A dengan malnutrisi juga diungkapkan oleh Oso (2003) di Nigeria yang menunjukkan bahwa anak yang mengalami malnutrsi kronik mempunyai kadar serum retinol lebih rendah dibandingkan dengan anak yang gizi baik. Ada sekitar $26,8 \%$ anak yang defisien serum retinol
$<10 \mu \mathrm{g} /$ dl dan $47,9 \%$ mempunyai kadar serum retinol kategori rendah $(10-19 \mu \mathrm{g} / \mathrm{dl})$.

Malnutrisi tetap merupakan salah satu penyebab utama kesakitan dan kematian pada anak-anak di seluruh dunia. Penelitian di rumah sakit pada anak yang mengalami malnutrisi menunjukkan bahwa suplementasi seng menghasilkan penurunan diare, infeksi pernafasan dan demam serta muntah pada anak yang malnutrisi. Kematian pada anak yang mendapat suplementasi seng juga lebih rendah secara signifikan dibandingkan dengan anak yang tidak mendapatkan seng. Prevalensi anakanak yang memiliki berat badan menurut umur di atas persentil 80 juga secara signifikan lebih tinggi pada anak-anak yang mendapat suplementasi seng (Makonnen, 2003).

Arsenault (2008) menungkapkan hasil penelitian pada anak-anak di Peru membuktikan bahwa anak-anak yang menerima suplementasi seng memiiliki berat tubuh lebih besar $0,41 \mathrm{~kg}$ dibandingkan dengan anak yang tidak mendapat seng dan terbukti bahwa defiseinsi seng dapat menghambat pertumbuhan. Shrimpton (2005) dan Penny (2004) melaporkan tentang manfaat suplementasi besi dalam proses pertumbuhan. Hal yang berbeda ditunjukkan oleh hasil penelitian Walker (2007) yang menyatakan tidak ada pengaruh suplementasi besi dengan atau tanpa seng terhadap pertumbuhan anak, namun penelitian ini menggunakan dosis yang rendah dan diberikan tidak setiap hari melainkan sekali dalam seminggu. Mekanisme yang pasti bagaimana seng dapat mempengaruhi pertumbuhan sampai saat ini belum jelas akan tetapi efek secara langsung yang telah diketahui adalah seng dapat menstimulasi rasa dan asupan energi serta meningkatkan massa bebas lemak pada tubuh (Arsenault, 2008). Hyder, (2007) menunjukkan bahwa fortifikasi mikronutrien pada anak remaja dapat menurunkan anemia, meningkatkan status mikronutrien dan status gizi remaja wanita di Bangladesh.

Lokasi penelitian merupakan wilayah perkotaan dengan kondisi lingkungan yang kumuh dan tingkat kepadatan penduduk yang cukup tinggi. Rata-rata tingkat kecukupan zat 
gizi $\mathrm{Fe}$, vitamin $\mathrm{C}$ dan vitamin $\mathrm{B} 1$, dan $\mathrm{Zn}$ masih rendah yaitu rata-rata dibawah $80 \%$ dari Angka Kecukupan Gizi (AKG) yang dianjurkan. Jumlah anak yang mengalami malnutrisi dengan kategori stunted (tinggi badan kurang menurut umur) sebesar 57,61\%, underweight (berat badan kurang menurut umur) sebesar $46,74 \%$, dan wasted (berat badan kurang menurut tinggi badan) sebesar 9,78\%. Penelitian ini bertujuan untuk mengetahui pengaruh intervensi suplementasi minuman terhadap status malnutrisi jangka panjang pada anak yang diukur berdasarkan status besi dan status vitamin A.

\section{METODE}

Penelitian quasi eksperimen ini dilakukan dengan memberikan intervvensi pada anak usia 1-3 tahun yang mengalami malnutrisi dan beresiko malnutrisi. Penentuan sampel dilakukan secara purposive dengan kriteria inklusi yaitu malnutrisi : berat badan kurang menurut umur, atau tinggi badan kurang menurut umur, dan berat badan kurang menurut tinggi badan berdasarkan kriteria dari WHO-NCHS, anak tidak cacat secara fisik, tidak ada kelainan kongenital serta ada pernyataan kesediaan dari subjek untuk menjalani pemeriksaan atau wawancara selama penelitian berlangsung. Lokasi penelitian di Kelurahan Sangkrah dan Semanggi, Kecamatan Pasar kliwon, Kota Surakarta.

Dalam pembuatan minuman suplemen multi-mikronutrien dibutuhkan bahan-bahan gula (sebagai pemanis sekaligus penghasil energi), essens, vitamin C:40 mg, vitamin B1:0,5 $\mathrm{mg}$, B2:0,5 mg, B6:0,5 mg, mineral Fe:8 mg, dan Zn:8,2 mg.. Dosis ditentukan berdasarkan AKG (Angka Kecukupan Zat Gizi) yang dianjurkan untuk anak usia 1-3 tahun. Alat ukur yang digunakan untuk pengumpulan data antropometri berupa timbangan dacin untuk mengukur berat badan anak, microtoise yang merupakan alat pengukur tinggi badan anak yang berusia di atas 2 tahun, dengan cara mengukur anak dalam keadaan berdiri. Baby board/wooden height board digunakan untuk mengukur panajang badan anak yang berumur kurang dari 2 tahun, yaitu dengan cara anak berbaring. Status hemoglobin anak dilakukan pemeriksaan darah dan dianalisis dengan metode cyanmethemoglobin, sedangkan untuk pengukuran status $\mathrm{Fe}$ dilakukan pengukuran serum ferritin metode ELISA dan mengukur status vitamin A dilakukan dengan metode penentuan serum retinol dengan cara HPLC (High Performance Liquid Chromatography).

Intervensi minuman suplemen diberikan pada anak malnutrisi sebanyak 76 anak. Pemberian minuman suplemen seebanyak satu kali setiap pagi hari selama 6 hari dalam 1 minggu selama 12 minggu intervensi. Petugas lapang diminta untuk mencatat kepatuhan dalam kartu khusus dan melihat secara langsung anak-anak tersebut minum hingga habis.

\section{HASIL DAN PEMBAHASAN}

Subjek penelitian ini adalah anak usia 1-3 tahun yang mengalami malnutrisi dan beresiko malnutrisi. Penentuan malnutrisi dilakukan dengan pengukuran antropometri berat badan dan tinggi bagan atau panjang badan anak.

Hasil penelitian menunjukkan bahwa rata-rata mendapatan keluarga yang mempunyai anak malnutrisi adalah $\mathrm{Rp} 861.333,50$. Ratarata pendapatan ini masih dibawah Upah Minimal Regional (UMR) untuk wilayah kota Surakarta yaitu sekitar Rp. 915.900,- Hal ini menunjukkan bahwa rata-rata tingkat ekonomi keluarga subjek adalah golongan menengah ke bawah. Selain itu apabila dilihat dari umur ibu dan umur ayah menunjukkan bahwa usia orangtua subjek bukan usia muda dan tergolong dalam kelompok produktif.

Status besi pada penelitian ini dilihat dari status anemia melalui pemeriksaan kadar hemoglobin dan status feritin anak yang malnutrisi dan beresiko malnutrisi. Kadar hemoglobin dan kadar feritin darah subjek masing-masing diperiksa dua kali yaitu sebelum diberikan intervensi minuman suplemen dan sesudah diberikan suplemen. Anak dikatakan anemia apabila dalam pemeriksaan kadar 
Tabel 1. Karakteristik anak malnutri peserta penelitian

\begin{tabular}{llll}
\hline Variabel & Rerata \pm SD & Minimal & Maksimal \\
& & & \\
\hline Usia (bulan) & $25,23 \pm 7,02$ & 12,85 & 38,30 \\
Berat Badan (kg) & $2,9 \pm 0,47$ & 1,24 & 4,00 \\
Frekuensi makan (kali) & $2,76 \pm 0,66$ & 1 & 5 \\
Usia mendapat & $4,47 \pm 3,99$ & 0 & 28 \\
MPASI (bulan) & & & \\
Usia berhenti minum ASI (bulan) & $15,59 \pm 9,57$ & 0 & 30 \\
Kadar Hb (mg/dL) & $11,50 \pm 0,93$ & 9,0 & 13,50 \\
Kadar Ferritin (umol/dL) & $17,19 \pm 10,89$ & 1,9 & 54,49 \\
Kadar Retinol (umol/dL) & $1,6 \pm 0,47$ & 0,49 & 2,51 \\
\hline
\end{tabular}

Tabel 2. Distribusi Status Anemia, Status Feritin dan status Retinol Subjek Sebelum dan Setelah Intervensi

\begin{tabular}{lll}
\hline Variabel & $\begin{array}{l}\text { Sebelum } \\
\text { Intervensi }\end{array}$ & $\begin{array}{l}\text { Setelah } \\
\text { Intervensi }\end{array}$ \\
\cline { 2 - 3 } & $\mathrm{n}(\%)$ & $\mathrm{n}(\%)$ \\
\hline $\begin{array}{l}\text { Status } \\
\text { Anemia }\end{array}$ & & \\
$\begin{array}{l}\text { Tidak } \\
\text { Normal }\end{array}$ & $19(25,0)$ & $9(11,8)$ \\
$\begin{array}{l}\text { Normal } \\
\text { Status Feritin }\end{array}$ & $57(75,0)$ & $67(88,2)$ \\
Tidak & $30(39,5)$ & $12(15,8)$ \\
Normal & $46(60,5)$ & $64(84,2)$ \\
$\begin{array}{l}\text { Normal } \\
\text { Status }\end{array}$ & & \\
Retinol & & \\
Tidak & $4(5,3)$ & $11(14,5)$ \\
Normal & & \\
Normal & $72(94,7)$ & $65(85,5)$ \\
\hline
\end{tabular}

hemoglobin menunjukkan nilai kurang dari 11 $\mathrm{mg} \%$.

Gambaran status anemia, status ferritin, status retinol subjek penelitian sebelum dan sesudah intervensi dapat dilihat pada Tabel 2.

Tabel 2 menunjukkan bahwa $25 \%$ subjek yaitu anak malnutrisi mengalami anemia. Hal ini menunjukkan bahwa malnutrisi berkaitan dengan defisiensi zat gizi yang lain dalam hal ini bisa zat besi, vitamin C, vitamin A atau zat gizi lain yang berhubungan dengan terjadinya anemia ditunjukkan dengan rendahnya kadar hemoglobin dalam darah. Setelah mendapatkan intervensi minuman suplemen setiap hari selama 12 bulan terjadi penurunan jumlah subjek yang mengalami kejadian anemia yaitu dari $25 \%$ menjadi $11,8 \%$. Hasil ini menunjukkan bahwa intervensi minuman suplemen dapat menurunkan angka kejadian anemia pada anak yang malnutrisi sebesar $13,2 \%$.

Pemeriksaan kadar feritin dalam darah juga merupakan salah satu pemeriksaan untuk menentukan diagnosa terjadinya defisiensi besi pada tubuh manusia. Pemeriksaan ini dilakukan untuk mengukur konsentrasi feritin atau cadangan besi di dalam tubuh. Sebesar $30 \%$ besi yang berada di dalam tubuh tersimpan sebagai feritin di limpa, sumsum tulang dan hati. Manfaat pemeriksaan feritin adalah untuk memantau perkembangan defisiensi besi pada penyakit anemia.

Pada pemeriksaan feritin awal sebelum subjek diberikan intervensi suplementasi terlihat sebanyak $60,5 \%$ termasuk dalam status feritin normal, sedangkan 39,5\% termasuk dalam status feritin tidak normal. Setelah dilakukan intervensi minuman suplemen selama 12 minggu terlihat bahwa status feritin subjek yang normal meningkat menjadi $84,2 \%$ dan yang tidak normal hanya $15,8 \%$. Hasil penelitian ini menunjukkan bahwa pemberian minuman suplemen dapat meningkatkan status feritin sebesarter 23,7\%. Hal ini menunjukkan bahwa minuman suplemenefektif meningkatkan status feritin anak yang malnutrisi.

Status vitamin A pada penelitian ini ditentukan dengan pemeriksaan serum retinol darah subjek. Pemeriksaan ini berguna untuk mengetahui terjadinya defisiensi vitamin A dalam tubuh. Defisiensi vitamin A sering dijumpai pada anak yang mengalami anemia atau anak yang mengalami malnutrisi. Defisiensi vitamin A dapat menyebabkan fungsi kekebalan tubuh menurun sehingga akan 
mudah terkenan penyakit infeksi. Apabila defisiensi vitamin A terjadi pada anak yang mengalami malnutrisi maka resiko komplikasi penyakit infeksi akan meningkat. Pada penelitian ditemukan sebesar $5,3 \%$ anak malnutrisi mempuyai kadar retinol awal sebelum diberikan suplementasi tidak normal.

Lokasi penelitian ini termasuk wilayah perkotaan dengan kondisi lingkungan yang kumuh dan tingkat kepadatan penduduk yang cukup tinggi, prevalensi anemia pada anak Batita cukup tinggi yaitu $25 \%$, dan tingkat kecukupan zat gizi baik makrto maupun mikro masih rendah yaitu dibawah $80 \%$ dari Angka Kecukupan Gizi (AKG), (Zulaekah, 2011). Hasil penelitian sebelumnya di wilayah yang sama menunjukkan bahwa tingkat konsumsi energi rata-rata $86,09 \pm 29,55 \%$, tingkat konsumsi protein rata-rata $101,80 \pm 43,23 \%$, tingkat konsumsi vitamin A rata-rata 122,66 \pm $75,72 \%$. Tingkat konsumsi vitamin rata-rata $63,41 \pm 48,21 \%$, tingkat konsumsi Fe rata-rata $60,27 \pm 42,37 \%$ dan tingkat konsumsi $\mathrm{Zn}$ ratarata $37,66 \pm 22,36 \%$ (Zulaekah, 2013).

Meskipun pada anak malnutrisi sudah diberikan intervensi minuman suplemen, tetapi terdapat peningkatan jumlah subjek yang mempunyai kadar retinol yang tidak normal, yaitu sebesar 9,2\%. Hal ini menunjukkan bahwa anak malnutrisi yang mempunyai kadar retinol tidak normal (rendah) belum bisa ditangani hanya dengan suplementasi dengan kandungan mikronutien vitamin A yang sesuai dengan AKG dalam waktu 12 minggu. Akan tetapi anak-anak tersebut perlu mendapatlkan perhatian dan penanganan yang lebih serius sehingga anak tidak akan jatuh pada defisiensi vitamin A yang lebih parah.

Pada penelitian ini, kejadian malnutrisi yang dilihat dari kekurangan energi dan protein berhubungan dengan defisiensi zat besi dan defisisensi vitamin A. Selain menyebabkan fungsi kekebalan tubuh menurun dan gangguan kesehatan mata, defisiensi vitamin A juga dapat menyebabkan terganggunya mobilisasi zat besi dalam hepar sehingga terjadi penurunan kadar feritin (Depkes RI, 2002). Gangguan mobilisasi zat besi juga akan menyebabkan rendahnya kadar zat besi dalam plasma, hal ini akan mengganggu proses sintesis hemoglobin sehingga menyebabkan rendahnya kadar hemoglobin dalam darah.

Malnutrisi sangat berkaitan dengan defisiensi berbagai mikronutrien, baik vitamin maupun mineral. Defisiensi mikronutrien, termasuk vitamin $\mathrm{A}$, zat besi dan seng menimpa lebih dari 3 milyar orang di dunia. Berdasarkan penelitian yang dilakukan oleh Centers for Disease Control and Prevention (CDC), anak kecil yang baru belajar berjalan usia 1-3 tahun memiliki resiko tinggi untuk defisiensi besi (Brotanek, 2008).

Pada penelitian di Nigeria oleh Oso (2003), menjelaskan bahwa anak yang mengalami malnutrsi kronik mempunyai kadar serum retinol lebih rendah dibandingkan dengan anak yang gizi baik. Ada sekitar 26,8\% anak yang defisien serum retinol $<10 \mu \mathrm{g} / \mathrm{dl}$ dan $47,9 \%$ mempunyai kadar serum retinol kategori rendah $(10-19 \mu \mathrm{g} / \mathrm{dl})$.

Suplementasi pada anak malnutrisi akan memperbaiki status anemia pada anak. AduAfarwuah $(2007,2008)$ mengungkapkan bahwa fortifikasi berbagai vitamin dan mineral dalam bentuk makanan pelengkap bayi terbukti dapat menurunkan prevalensi defisiensi besi pada bayi. Selanjutnya Öhlund (2008) membuktikan pada anak-anak yang bergizi baik (tidak malnutrisi), prevalensi anak-anak yang mengalami defisiensi besi lebih rendah dibandingkan dengan anak-anak yang bergizi baik. Beberapa prevalensi penyakit sering dikaitkan juga defisiensi mikronutrien, dan dengan suplemtasi dapat mengurangi risiko penyakit. Sesuai hasil sistematik review menyimpulkan suplementasi seng secara signifikan dikaitkan dengan pengurangan insiden dan prevalensi pneumonia di antara anak-anak berusia dua hingga 59 bulan (Lassi, 2016).

Mikronutrien seperti vitamin A, vitamin $\mathrm{B}$, vitamin $\mathrm{C}$, folat, seng, kalsium, iodium dan besi sangat efektif untuk memperbaiki defisisensi defisiensi zat gizi, termasuk defisiensi vitamin A. Defisiensi vitamin A merupakan masalah kesehatan yang sangat serius di dunia, 
karena defisiensi ini penyebab utama terjadinya kebutaan pada anak-anak. Makanan yang difortifikasi dan meningkatkan konsumsi buah dan sayur dalam makanan juga penting sebagai salah satu cara untuk mengurangi terjadinya defisiensi vitamin A (Torpy, 2004).

Malnutrisi akibat defisiensi mikronutrien biasanya terjadi secara simultan. Hasil penelitian Hyder (2007) menunjukkan bahwa intervensi multimikronutrien dapat menurunkan kejadian anemia lebih besar dibandingkan dengan kelompok tunggal, demikian pula dengan perubahan status vitamin A dan status Zn yang menunjukkan efek yang lebih baik dibanding dengan kelompok kontrol. Hasil penelitian lain pada remaja wanita menunjukkan bahwa suplementasi vitamin A, besi dan seng lebih efektif meningkatkan hemoglobin dibanding yang mendapatkan suplementasi vitamin A dan besi (Cusick, 2005). Penelitian lain juga menyimpulkan bahwa suplementasi vitamin A menurunkan diare pada anak-anak dari rumah tangga dengan lantai tanah. Suplementasi seng menurunkan diare pada anak-anak dari rumah tangga dengan lantai tanah dan yang ibunya berpendidikan lebih tinggi (Long, 2006).

Hasil penelitian ini juga menunjukkan bahwa dalam menangani masalah malnutrisi dan anemia pada anak tidak cukup dengan intervensi suplementasi multimikronutrien saja. Kombinasi dengan kegiatan lain perlu dilakukan, misalnya dengan memberikan pendidikan gizi pada ibu atau keluarga yang mengasuh anak tersebut. Harapan pendidikan gizi ini adalah pengetahuan dan sikap ibu atau keluarga tentang kebutuhan zat gizi anak dan cara memberikan makan anak yang baik dan benar akan meningkat. Selanjutkan sikap dan perilaku ibu dan keluarga tentang cara pemberikan makan pada anak menjadi lebih baik. Harapan selanjutnya asupan zat gizi anak baik makronutrien maupun mikronutrien akan meningkat. Hal ini sesuai dengan penelitian Zulaekah, 2012 bahwa pendidikan gizi yang dilakukan secara periodik efektif dapat meningkatkan pengetahuan gizi sebesar 17,44 point. Secara statistik ada perbedaan bermakna pengetahuan gizi sebelum dan sesudah diberikan intervensi pendidikan gizi.

\section{PENUTUP}

Intervensi minuman suplemen dapat menurunkan angka kejadian anemia pada anak yang malnutrisi sebesar 13,2\%. Pemberian minuman suplemen dapat meningkatkan status feritin sebesar 23,7\%. Hal ini menunjukkan bahwa minuman suplemen efektif meningkatkan status feritin anak yang malnutrisi. Meskipun sudah diberikan intervensi minuman suplemen pada anak yang malnutrisi akan tetapi terdapat peningkatan jumlah subjek yang mempunyai kadar retinol yang tidak normal sebesar $9,2 \%$.

Waktu tiga bulan belum cukup untuk mengembalikan atau memperbaiki status gizi yang kurang pada anak yang mengalami malnutrisi, sehingga dibutuhkan perhatian khusus dan memerlukan waktu yang lama untuk dapat menangani masalah ini supaya dampak yang timbul tidak akan lebih parah. Selain itu kombinasi dengan kegiatan yang lain seperti pendidikan gizi bagi ibu dan keluarga perlu dilakukan untuk meningkatkan hasil yang maksimal.

\section{DAFTAR PUSTAKA}

Adu-Afarwuah, S., Lartey, A., Brown, KH., Zlotkin, S., Briend, A., Dewey, KG. 2008. Home fortification of complementary foods with micronutrient supplements is well accepted and has positive effects on infant iron status in Ghana. American Journal of Clinical Nutrition; 87(4): 929-938.

Adu-Afarwuah, S., Lartey, A., Brown, KH., Zlotkin, S., Briend, A., Dewey, KG. 2007. Randomized comparison of 3 types of micronutrient supplements for home fortification of complementary foods in Ghana: effects on growth and motor development. Am. J. Clin. Nutr.; 86(2): 412420.

Arsenault, JE., de Romaña, DL., Penny, ME., Van Loan, MD., Brown, KH. 2008. Additional Zinc Delivered in a Liquid Supplement, but Not in a Fortified Porridge, Increased Fat- 
Free Mass Accrual among Young Peruvian Children with Mild-to-Moderate Stunting . $J$. Nutr; 138:108-114.

Berger, SG., de Pee, S., Bloem, MW., Halati, S. and Semba, RD. 2007. Malnutrition and Morbidity Are Higher in Children Who Are Missed by Periodic Vitamin A Capsule Distribution for Child Survival in Rural Indonesia. J. Nutr. 137: 1328-1333.

Brotanek, JM., Gosz, J.. Weitzman, M. \& Flores. (2007) iron deficiency in early childhood in the united states : risk factors and racial/ethnic disparities. Pediatrics [Internet], 121 (3), pp 568-575. Available from : $<$ pediatrics.aappublications.org/cgi/content/f ull/120/3/568> [Accessed 21 October 2009]

Cusick, HE., Tielsch, JM., Ramsam, M., Jape, JK., Sazawal, S, Balack, RE., Stolzfus, RJ. 2005. Am J Clin Nutr82: 406-12

DepKes. RI. 2002. Buku pegangan Tenaga Kesehatan Deteksi Dizi Xeroptalmia, Jakarta.

Databoks Katadata. 2019. 17,7\% Balita Indonesia Masih Mengalami Masalah Gizi. Diakses dari situs

https://databoks.katadata.co.id/datapublish/ 2019/01/25/177-balita-indonesia-masihmengalami-masalah-gizi pada 08 Juni 2020

Hyder, SMZ., Haseen, F., Khan, M., Schaetzel,T., Jalal, CSB., Rahman, M., Lönnerdal, B., Mannar, V., Mehansho, H. 2007. A MultipleMicronutrient-Fortified Beverage Affects Hemoglobin, Iron, and Vitamin A Status and Growth in Adolescent Girls in Rural Bangladesh . J. Nutr. 137:2147-2153.

Kemenkes RI, 2013. Laporan Riset Kesehatan Dasar 2013. Kementerian Kesehatan Republik Indonesia, Jakarta.

Lassi, Z. S., Moin, A. and Bhutta, Z. A. (2016) 'Zinc supplementation for the prevention of pneumonia in children aged 2 months to 59 months', Cochrane Database of Systematic Reviews, 2016(12). doi: 10.1002/14651858.CD005978.pub3.

Long, K. Z. et al. (2006) 'A double-blind, randomized, clinical trial of the effect of vitamin $\mathrm{A}$ and zinc supplementation on diarrheal disease and respiratory tract infections in children in Mexico City,
Mexico', American Journal of Clinical Nutrition, 83(3), pp. 693-700. doi: 10.1093/ajcn.83.3.693.

Öhlund, I., Lind, T., Hörnell, A., Hernell, O. 2008. Predictors of iron status in well-nourished 4-yold children. American Journal of Clinical Nutrition; 87(4), 839-845.

Oso, OO., Abiodun, PO., Omotade, OO., and Oyewole, D. 2003. Vitamin A Status and Nutritional Intake of Carotenoids of Preschool Children in Ijaye Orile Community in Nigeria. Journal of Tropical Pediatrics, 49(1):42-47.

Penny, ME., Marin, RM., Duran, A., Peerson, JM., Lanata, CF., Bo Lönnerdal, Black, RE., Brown, KH. 2004. Randomized Controlled Trial Of The Effect Of Daily Supplementation With Zinc Or Multiple Micronutrients On The Morbidity, Growth, And Micronutrient Status Of Young Peruvian Children. Am J Clin Nutr;79:457-65.

Shrimpton, R., Gross, R., Darnton-Hill, I., Young. M. 2005. Zinc deficiency: what are the most appropriate interventions? BMJ ;330;347-349

Torpy, JM., Cassio Lynm; Richard M. Glass. 2004. Malnutrition in Children JAMA;292(5):648.

UNS/SCN. 2005. 2005. Crisis Situations Report $n^{\circ}$ 6 - Summary. United Nations System Standing Committee on Nutrition. Geneva.

Walker, CLF., A H Baqui, S Ahmed, K Zaman, S El Arifeen, N Begum, M Yunus, R E Black, and L E Caulfield. 2007. Low-dose weekly supplementation with iron and/or zinc does not affect growth among Bangladeshi infants FASEB J; 21: A681.

Zulaekah, S., Purwanto, S., Hidayati, L. 2011. Perkembangan Motorik, Status Gizi

dan Kadar $\mathrm{Hb}$ Anak Malnutrisi di Kota Surakarta. Laporan Penelitian

Reguler Kompetitif UMS. Surakarta

Zulaekah,S., Purwanto,S dan Hidayati,L. 2014. Anemia terhadap Pertumbuhan dan Perkembangan Anak Malnutrisi. Jurnal Kemas. Unnes. 9(2):106-114

Zulaekah,S.2012. Pendidikan Gizi Dengan Media Booklet Terhadap Pengetahuan Gizi. Jurnal Kemas. Unnes. 7(2):121-128 